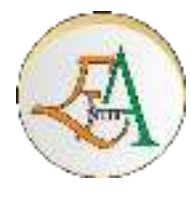

ENTITA : Jurnal Pendidikan Ilmu Pengetahuan Sosial dan Ilmu-Ilmu Sosial

http://ejournal.iainmadura.ac.id/index.php/entita

P-ISSN:2715-7555 E-ISSN:2716-1226

\title{
Implementasi Pendekatan Multikultural dalam Upaya Meningkatkan Kesadaran Kebhinekaan Menuju Masyarakat Madani
}

\author{
Wahyu Setyaningsih \\ IAIN Salatiga \\ wahyusetyaningsih@iainsalatiga.ac.id
}

\begin{abstract}
Globalization that happened in Indonesia bring into being the destroyed of cultural value. The multicultural of culture, social, and religion can not be avoided by Indonesian's society. The one cause of many conflicts that happened in Indonesia is the weakness of understanding and meaningful about cultural ability. The awareness of multicultural in Indonesia did not buried in mind's Indonesian citizen. The objectives of this article are 1. To know the general illustration about the Indonesian condition of age. 2. To know the strategies effort by multicultural approach to create the awareness of multicultural to concerned at civil society. 3. To know the effect of multicultural approach implementation to create the awareness of Indonesian multicultural. This article created by literature study like books, journals, and research report, news paper, and websites. The process of data analysis is done by descriptive. The process of written is created by the appropriate systematically from observation of problem until the recommendation of suggestion to continuing act.From the result of data analysis we can got the conclusion that multicultural approach implementation in increasing the multicultural awareness to become civil society will growth and develop the tolerances between one cultural with another cultural in Indonesian society so it can create civil society that is right and duty between human is same.
\end{abstract}

Keywords: awareness of multicultural, approach multicultural and civil society..

Abstrak

Globalisasai yang terjadi di Indonesia menjadikan memudarnya nilai-nilai luhur budaya bangsa. Keberagaman dari budaya, sosial kultural maupun agama tidak dapat terhidarkan oleh masyarakat Indonesia. Salah satu penyebab utama terjadi berbagai konflik di Indonesia adalah lemahnya pemahaman dan pemaknaan tentang konsep kearifan budaya. Kesadaran akan kebhinekaan budaya yang ada di Indonesia belum tertanam dalam benak setiap warga Indonesia. Tujuan dari penulisan ini meliputi : pertama, mengetahui gambaran umum tentang kondisi bangsa Indonesia dewasa ini. Kedua, mengetahui upaya-upaya strategis yang dilakukan dalam mewujudkan kesadaran kebhinekaan melalui pendekatan multukultural. Ketiga, mengetahui implementasi pendekatan multikultural dalam mewujudkan kesadaran kebhinekaan menuju masyarakat madani. Artikel ini disusun melalui studi pustaka yang berupa buku, jurnal dan laporan penelitian, observasi, surat kabar dan web site. Proses analisa data dilakukan secar deskriptif. Penulisan ini disusun sesuai dengan sitematika dimulai dari pengamatan terhadap permasalahan sampai pada rekomendasi saran-saran untuk ditindak lanjuti. Hasil dari anaslis data yang diperoleh dapat ditarik kesimpulan bahwa implementasi pendekatan multikultural dalam meningkatkan kesadaran kebhinekaan menuju masyarakat madani adalah melalui menumbuhkembangkan rasa saling menghormati antara kebudayaan satu dengan yang lain pada masyarakat sehingga dapat mewujudkan masyarakat madani yaitu hak dan kewajiaban antar manusia adalah sama. Diharapkan segala bentuk diskriminasi, kekerasan dan ketidakadilan yang sebagian besar dilatarbelakangi oleh adanya perbedaan kultural seperti perbedaan agama, ras, etnis, bahasa, kemampuan, gender, umur dan kelas sosisal-ekonomi dapat diminimalkan atau dihindari.

Kata Kunci: kesadaran kebhinekaan, pendekatan multikultural, dan masyarakat madani.

\begin{tabular}{|c|c|}
\hline Received : 3 May 2021 & Revised: 1 June 2021 ; Accepted: 8 Juni 2021 \\
\hline $\begin{array}{l}\text { (c) ENTITA : Jurnal Pendidikan IImu } \\
\text { Pengetahuan Sosial dan IImu-IImuSosial }\end{array}$ & https://doi.org/10.19105/ejpis.v3i1. (c) () () \\
\hline
\end{tabular}




\section{Pendahuluan}

Globalisasi adalah era yang tidak dapat ditawar lagi dan tidak dapat dihindari oleh setiap bangsa. Globalisasi dapat menjadikan peluang setiap bangsa untuk menjadi terkenal manakala mampu tampil ke wajah dunia dengan segudang prestasi dan dapat menjadi kiblat negara-negara dunia manakala daya tawar begitu menarik. Namun sebaliknya, globalisasi menjadikan negara-negara kehilangan idiologinya bahkan jatidiri sebagai sebuah Negara hancur ditelan pusaran globalisasi. Maka, globalisasi tanpa batas ruang dan waktu mampu merubah sebuah negara manakala negara tersebut tidak mempunyai daya imun yang kuat untuk menangkal globalisasi karena globalisasi membawa perubahan dalam segala aspek kehidupan.

Indonesia sebagai negara berkembang yang mempunyai potensi alam dan potensi manusia serta potensi kebudayaan. Namun, potensi tersebut belum teroptimalkan. Keberagaman dalam berbagai etnik, sosio-kultural tidak dapat terlepas dari kehidupan masyarakat Indonesia. Dari setiap daerah dari sabang sampai merauke hidup dan berkembang berbagai kebudayaan yang beraneka ragam. Era reformasi, keterbukaan dan otonomi daerah mampu menjadi potensi strategis bagi negara-negara asing untuk menghancurkan Indonesia melalui pengambilan sumber potensi lain yang belum diolah oleh Indonesia. Oleh karena itu diperlukan ketahanan nasional untuk menghindari hal tersebut.

Keberagamaan di Indonesia merupakan ancaman untuk menuju disintegrasi bangsa manakala berbagai permasalahan perbedaan etnik daerah menjadi persoalan yang tak kunjung berakhir. Berbagai konflik sosial dan politik di Republik ini juga masih menyisakan potensi yang mengancam persatuan bangsa seperti yang pernah terjadi di Aceh, Maluku, Poso, Papua Barat, dan sebagainya. Beberapa gerakan rakyat bahkan menuntut kemerdekaan, lepas dari kesatuan Republik Indonesia. Mereka ingin mendirikan negara sendiri sebagaimana yang telah terjadi dengan Timor Timur. Hal ini disebabakan karena kegagalan pemerintah dalam menjaga keseimbangan antar kelompok dalam masyarakat (Abdullah, 2003: 9).

Dewasa ini berbagai konflik yang diakibatkan oleh perbedaaan agama berkembang pesat. Konflik Ahmadiyah di Banten yang banyak memakan korban. Konflik agama lain juga terjadi di daerah Temanggung. Hal ini merupakan hal yang tragis terjadi di Indonesia, karena di Indonesia terdapat enam agama yang mendapat perlindungan hukum yaitu agama Islam, agama Kristen, agama Budha, agama Hindu, agama Katolik dan agama Konghucu. Namun, kesadaran untuk saling toleransi antara agama sangat rendah 
Krisis ekonomi yang melanda di Indonesia sampai sekarang masih menyisakan berbagai penderitaan rakyat. Masih banyak rakyat hidup di bawah garis kemiskinan. Kasus kelaparan, pengangguran dan putus sekolah masih menjadi warna kelabu bagi bangsa Indonesia yang tidak kunjung selesai. Mesipun sudah banyak program-program pemerintah dalam rangka penanggulan kemiskinan seperti Program Pembinaan dan Peningkatan pendapatan petani dan nelayan kecil (P4K), Program Tabungan dan Kredit Usaha Kesejahteraan Rakyat (Takesra-Kukesra), Program Pengembangan Kecamatan (PPK), Jurnal Analisa Sosiologi 3 (1) 83 Program Penanggulangan Kemiskinan Perkotaan (P2KP), Program Pembangunan Prasarana Pendukung Desa Tertinggal (P3DT), dan sebagainya. Namun, kesejahteraan masyarakat belum dapat terealisasikan secara merata (Solikatun et al., 2018: 82-83).

Akhir-akhir ini Indonesia dihadapkan pada mafia kasus. Berbagai kasus korupsi yang terjadi di Negara Indonesia banyak menyeret tokoh-tokoh pemerintahan hal ini menjadikan tidak kepercayaan publik kepada pemerintah. Korupsi yang terjadi tidak lepas dari politik uang. Hal ini akan menimbulkan berbagai permasalahan baru seperti mereduksi demokrasi atau kedaulatan rakyat dan bahkan pelayanan publik yang diberikan oleh pejabat pemerintah diprioritaskan kepada rakyat yang membayarnya. Hal ini banyak sekali terjadi tidak hanya pada scope tinggi saja tetapi scope yang paling rendah sekalipun. Maka nilai penting dari demokrasi di Indonesai belum sepenuhnya terwujudkan untuk seluruh lapisan masyarakat.

Dari permasalahan di atas maka diperlukan upaya mencari sebuah solusi untuk memperbaiki pola pemikiran masyarakat Indonesia yang cenderung melihat suatu perbedaan bukan sebagai khasanah budaya bangsa dan sikap yang tidak mau memikirkan penderitaan orang lain. Hal ini memerlukan sebuah kesadaran kebinekaan dari seluruh rakyat Indonesia agar tercipta suatu tatanan keharmonisan antara penghuni dan lingkungannya. Solusi tersebut adalah dengan melakukan pendekatan multikultural terhadap keberagaman yang ada di Indonesia sehingga didapatkan sebuah sebuah ideology yang mengakui dan mengagungkan perbedaan dalam kesederajatan baik secara individual maupun secara kebudayaan tanpa harus menimbulakan konflik yang akan mengarah kepada disintegrasi bangsa. Pemikiran inilah yang kemudian melatarbelakangi penulisan karya tulis yang berjudul "Implementasi Pendekatan Multikultural dalam Upaya Meningkatkan Kesadaran Kebhinekaan Menuju Masyarakat Madani”. 


\section{Metode}

Artikel ini disusun melalui berbagai studi pustaka, yang berupa buku, jurnal dan laporan penelitian, surat kabar dan web site. Proses analisa data dilakukan secara deskriptif.

Penulisan ini dilakukan dengan berbagai tahap sebagai berikut ini.

1. Mengamati dan menganalisis permasalahan tentang keanekaragaman agama, etnik dan sosio-kultural di Indonesia yang dapat memicu disintegrasi bangsa sehingga di butuhkan adanya upaya untuk menjadikan keberagaman sebagai pemersatu bangsa Indonesia untuk mewujudkan Indonesia yang sejahtera, adil dan demokratis melalui pendekatan multikultural.

2. Mempelajari informasi dari kajian pustaka dan beberapa hasil penelitian bahwa pendekatan multikultural mampu menyadarkan kebhinekaan untuk menuju masyarakat madani yaitu dengan cara hidup menghormati, tulus, dan toleran terhadap keanekaragaman budaya yang hidup di tengah-tengah masyarakat plural.

3. Merumuskan masalah tentang implementasi pendekatan multicultural dalam mewujudkan kesadaran kebhinekaan Indonesia untuk menuju masyarakat madani.

4. Mengumpulkan data dan informasi dari berbagai sumber, yaitu literatur pada media cetak dan elektronik serta data-data akurat yang diperoleh dari jurnal dan laporan hasil penelitian.

5. Menjabarkan rumusan masalah dengan menggunakan literatur-literatur yang paling relevan, relevan dan cukup relevan dari berbagai sumber yang telah diperolehnya dan dianalisis secara deskripsif. Hasil penjabaran rumusan masalah tertuang dalam hasil dan pembahasan.

6. Mengambil kesimpulan sesuai dengan perumusan masalah.

7. Merekomendasikan saran-saran untuk penerapan penelitian dan penulisan selanjutnya.

\section{Hasil dan Pembahasan}

\section{A. Gambaran Umum Kondisi Indonesia Dewasa ini}

Indonesia merupakan negara majemuk baik dalam kebudayaan, sosial, ekonomi dan sebagainya. Berbagai perbedaaan tersebut dijadikan sensitivitas yang berpotensi memicu konflik antar daerah. Kekerasan antar kelompok yang meledak secara sporadis di berbagai kawasan Indonesia menunjukkan betapa rendahnya rasa toleransi akan perbedaan. Konflik sosial yang bernuansa SARA (suku, agama, dan ras) merupakan salah faktor penyebab terjadinya konflik antar daerah. Faktor 
utamanya adalah lemahnya pemahaman dan pemaknaan tentang konsep kearifan budaya yang menjadikan pergolakan di daerah.

Berbagai konflik sosial ditimbulkan oleh kurangnya kemauan untuk menerima dan menghargai perbedaan seperti ide dan pendapat orang lain, karya dan jerih payah orang lain, melindungi yang lemah dan tak berdaya, menyayangi sesama, kurangnya rasa kesetiakawanan sosial dan kepekaan sosial. Selain itu, berbagai konflik kedaerahan yang sering terjadi diiringi oleh ketiadaan pemahaman akan keberagaman atau multikultur (Ibrahim, 2013: 132).

Globalisasi membuka peluang adanya krisis sosial-budaya yang terjadi di kalangan masyarakat, terutama generasi muda. Semakin meningkatnya penetrasi dan ekspansi budaya Barat tanpa diiringi oleh filterisasi sehingga memunculkan kecenderungan-kecenderungan "gaya hidup" baru yang tidak selalu positif dan kondusif bagi kehidupan sosial budaya masyarakat dan bangsa Hal ini menyebabkan budaya lokal atau budaya bangsa semakin tidak dikenal oleh generasi muda (Abdullah, 2003: 8).

Konflik kekuasaan dalam negeri terus berlanjut. Munculnya berbagai elit politik, terutama pada waktu pemilihan umum baik di tingkat lokal maupun nasional. Serangan fajar berupa uang yang dibagikan kepada masyarakat masih marak terjadi terutama di daerah-daerah pelosok yang belum melek pengetahuan. Ini menunjukkan rakyat Indonesia belum memiliki komitmen tinggi untuk menegakkan supremasi hukum dan HAM, sehingga ketidaktertiban dan pelanggaran hukum tetap menjadi fakta sosial.

Dengan demikian Indonesia berada pada penjajahan meskipun bukan penjajahan dalam konteks masa lalu. Seperti ungkapan Edward Said bahwa gejala ini tidak lain daripada cultural imperialism baru, menggantikan imperialisme klasik yang terkandung dalam orientalisme. Hal ini dapat mengakibatkan lenyapnya identitas kultural nasional dan lokal, padahal identitas nasional dan lokal tersebut sangat krusial bagi integrasi sosial, kultural dan politik masyarakat dan negara-bangsa.

\section{B. Upaya-Upaya Strategis dalam Meningkatkan Kesadaran Kebhinekaan melalui Pendekatan Multikultural}

Pendidikan merupakan sarana efektif dalam melakukan perubahan, begitu juga untuk meningkatkan kesadaran kebhinekaan melalui pendekatan multikultural. Maka diperlukan upaya untuk memberikan kebebasan yang bertanggung jawab bagi para pelaku pendidikan. Pendekatan multikultural mulai dikembangkan untuk 
membentuk jiwa saling menghormati dan menghargai antar satu individu dengan individu lainnya dengan latar belakang sosio kultural, historis yang berbeda sehingga keberadaan orang-orang dari kelompok minoritas mendapat pengakuan (Khairah, 2020: 32).

Menurut Sitaresmi, multikulturalisme dapat dilakukan melalui dua cara yaitu: a) secara langsung menyampaikan pesan tentang multikulturalisme dengan memberi contoh kehidupan sehari-hari; dan b) secara tidak langsung melalui cerita yang dikemas dalam dongeng atau yang lainnya yang berisi pesan tentang multikulturalisme. Selain itu dapat juga dilakukan melaui kegiatan formal dan kegiatan informal (Rahmawati, 2014: 7).

Kesadaran kebinekaan dapat dilakukan melalui berbagai dimensi seperti pertama, dimensi integrasi isi/materi (content integration). Dalam setiap pembelajaran seorang pendidik memberikan refleksi tentang pentingnya kesadaran kebinekaan dalam kehidupan bermasyarakat. Kedua, dimensi konstruksi pengetahuan (knowledge construction). Setiap lembaga pendidikan membuat kebijakan untuk mampu mencover kesadaran kebhinekaan misalnya memuat kurikulum tentang multikultural. Ketiga, Dimensi pengurangan prasangka (prejudice ruduction) yaitu setiap individu mempunyai kesadaran bahwa keberaneka ragam yang ada justru sebagai tempat belajar bukan malah berfikr negatif yang menjadikan perbedaan sebagai pemicu disintegrasi. Keempat, dimensi pendidikan yang sama/adil (equitable pedagogy) yaitu semua mendapatkan fasilitas pendidikan secara adil tanpa ada pengecualian sehingga semua mendapatkan keadilan hak dan kewajiban. Keilima, dimensi pemberdayaan budaya kampus dan struktur sosial (empowering school culture and social structure). Memperdayakan budaya mahasiswa yang berasal dari kelompok yang berbeda. Di samping itu, dapat digunakan untuk menyusun struktur sosial (kampus) yang memanfaatkan potensi budaya mahasiswa yang beranekaragam sebagai karakteristik struktur kampus setempat, misalnya berkaitan dengan praktik kelompok, iklim sosial, latihan-latihan, partisipasi ekstra kurikuler dan penghargaan staff dalam merespon berbagai perbedaan yang ada di kampus. Maka dengan adanya pemberdayaan budaya kampus kesadaran akan kebhinekaan dapat terealisasi (James A. Banks, 2002: 14)

Upaya strategis lainnya dapat melalui pertama, mengedepankan semangat kekeluargaan (fratenity), misalnya melalui kegiatan musyawarah dalam memecahkan permasalahan. Kedua, solidaritas sosial (solidarity), misalnya melalui kegiatan saling berbagi dan membantu orang-orang yang membutuhkan masalah. Ketiga, prinsip 
keadilan (justice) misalnya dalam pemberian tugas tidak membedakan-bedakan tetapi sesuai dengan tupoksi masing-masing. Keempat, kesederajatan (egality), semua orang diperlakukan secara sama tidak ada pengecualian. kelima, kebebasan (liberty) mengembangkan diri. Setiap orang yang mempunyai potensi untuk berkembang diberikan kebebasan tidak malah dibatasi akan kemampuan yang dimiliki. Keenam, peluang dan kesempatan (opportunity) yang sama dalam mengejar prestasi individu. Maka dengan membiasakan hal tersebut dapat meningkatkan kesadaran kebhinekaan baik dalam kondisi formal maupun nonformal.

Dengan demikian upaya-upaya strategis dalam meningkatkan kesadaran kebhinekaan sarat dengan keberagaman atau kebhinekaan baik dari berbagai golongan maupun pihak-pihak lain yang terdapat di dalamnya maka perlu menghindari pandangan etnosentri dan fanatik golongan. Antara berbagai golongan harus saling berbaur sehingga tidak terdapat kelompok-kelompok eksklusif yang akan menonjolkan kelompoknya tanpa menghargai dan menghormati kelompokl lain. Maka, pembentukan karakter yang terbuka terhadap perbedaan sangat penting untuk mewujudkan kebhinekaan (Ibrahim, 2013: 132).

\section{Implementasi Pendekatan Multikultural dalam Upaya Meningkatkan Kesadaran Kebhinekaan Menuju Masyarakat Madani}

Semboyan Bhineka Tunggal Ika dapat terimplementasikan melalui pendekatan multikultural. Selain itu, memberi dorongan dan spirit bagi lembaga pendidikan nasional untuk mau menanamkan sikap kepada peserta didik untuk menghargai orang, budaya, agama, dan keyakinan lain. Harapannya, dengan implementasi pendidikan yang berwawasan multikultural, akan membantu mahasiswa mengerti, menerima dan menghargai orang lain yang berbeda suku, budaya dan nilai kepribadian. Lewat penanaman semangat multikulturalisme di kampus akan menjadi medium pelatihan dan penyadaran bagi generasi muda untuk menerima perbedaan budaya, agama, ras, etnis dan kebutuhan di antara sesama dan mau hidup bersama secara damai.

Dalam kehidupan bermasyarakat implikasi dari pendekatan multikultural adalah adanya pandangan keberagaman sebagai satu kesatuan dalam wadah kebhinekaan dalam kehidupan bermasyarakat, berbangsa dan bernegara, maka berbagai bentuk pembangunan, modernisasi dan globalisasi tidak menjadi ancaman dalam mewujudkan masyarakat madani. Maka diperlukan upaya untuk mencegah 
akibat negative dari globalisasi, salah satu upayanya adalah dengan implementasi pendekatan multikultural. Implementasi tersebut diperlukan kerjasama dari berbagai pihak baik itu pemerintah maupun rakyat.

Implementasi pendekatan multikultural adalah memahami latar belakang diri dan kelompok dalam masyarakat kampus. Implementsi pendekatan multikultural lainnya adalah setiap mahasiswa atau jurusan mempunyai kemampuan berinteraksi dan bertransaksi meskipun latar belakang kultur masing-masing berbeda. Hal ini karena keberagaman kultur mengandung unsur jamak serta sarat dengan nilai-nilai kearifan. Maka nilai-nilai kearifan itu, dapat dijadikan sebagai sumbu pengikat dalam berinteraksi dan bersosialisasi antar masyarakat melalui kemampuan berinterakasi sehingga tercipta suasana yang damai dan harmonis, bukan suasana yang tegang.

Implementasi pendekatan multikultural ini bermanfaat dalam membentuk pemikiran kolektif yaitu suatu pemikiran yang konstruktif dan progresif untuk menyongsong kehidupan yang lebih baik. Oleh karena itu untuk mewujudkannya semua pihak atau seluruh warga Indonesia haruslah meningkatkan sikap, perilaku, dan tanggungjawab yang konstruktif untuk menjadikan masa depan lebih baik dan lebih cemerlang dibandingkan tahun sekarang dan tahun lampau. Bangsa Indonesia harus mampu mencapai dan mewujudkan keadilan dan kesejahteraan sosial bagi seluruh warga Indonesia dengan peran serta semua pihak.

Implementasi terhadap usaha untuk kesadaran kebhinekaan pada masyarakat merupakan peran penting institusi pendidikan dalam merumuskan, mengembangkan serta mewujudkan mahasiswa multikultural melalui kampus atau sekolah sebagai pilar utama. Lembaga pendidikan baik formal maupun informal adalah bentuk lain dari miniatur masyarakat, yang elemennya terdiri dari unsur yang berlatar belakang berebeda, sehingga lembaga pendidikan juga dapat membentuk diri sebagai kerangka kehidupan berdemokrasi dalam setiap interaksi maupun sosalisasi ditengah-tengah aktivitas pendidikan. Oleh karena itu, institusi pendidikan merupakan bentuk instutusi efektif yang diharapkan dapat mengembangkan gagasan kehidupan multkultur secara praktis, melalui jaringan pendidikan yang sistematis dan terprogram melaui kesadaran kebhinekaan pada diri peserta didik dan tenaga pendidik.

Dengan demikian implementasi pendekatan multikultural dalam upaya meningkatkan kesadaran kebhinekaan menuju masyarakat madani yaitu masyarakat harus meninggalakan sikap-sikap yang terlalu etnosentris dan penuh prasangka, mahasiswa harus memahami faktor-faktor sosial, ekonomis, psikologis, dan historis yang tidak menyebabkan terjadinya polarisasi etnik ketimpangan dan keterasingan 
etnik, mahasiswa harus meningkatkan kemampuan menganalisis secara kritis masalah-masalah rutin dan isu melalui proses demokratis lebih baik, adil dan bebas dan mengembangkan jati diri yang bermakna bagi semua orang. Hal itu harus diimbangi dengan peran serta dari berbagai pihak baik pemerintah, swasta maupun rakyat.

\section{Kesimpulan}

1. Gambaran umum tentang kondisi Indonesia dewasa ini adalah dalam berbagai bidang kehidupan masih mengalami permasalahan baik dari bidang ekonomi, sosial kultural, politik dan pemerintahan dan pendidikan sehingga Indonesia masih sulit mewujudkan tujuan nasional yang tertuang dalam pembukaan dang Dasar 1945, masih banyak rakyat hidup dalam garis kemiskinan, kesejahteraan belum merata secara menyeluruh, ketimpangan social masih menjadi permasalahan, demokrasi masih dikendalikan oleh uang atau elit pejabat dan keadialan dalam berbagai segi kehidupan masih jauh dari harapan.

2. Upaya-upaya strategis dalam meningkatkan kesadaran kebhinekaan menuju masyarakat madani melalui pendekatan multikultural adalah perlu menghindari pandangan etnosentri dan fanatik golongan. Antara berbagai ras, suku bangsa, golongan saling berbaur sehingga tidak terdapat kelompok-kelompok eksklusif yang akan menonjolkan kelompoknya tanpa menghargai dan menghormati kelompok lain.

3. Implementasi pendekatan multikultural dalam upaya meningkatkan kesadaran kebhinekaan menuju masyarakat madani yaitu masyarakat Indonesia harus meninggalakan sikap-sikap yang terlalu etnosentris dan penuh purbasangka, mahasiswa harus memahami faktor-faktor sosial, ekonomis, psikologis, dan historis yang tidak menyebabkan terjadinya polarisasi etnik ketimpangan dan keterasingan etnik, mahasiswa harus meningkatkan kemampuan menganalisis secara kritis masalah-masalah rutin dan isu melalui proses demokratis yang lebih baik, adil dan bebas dan mengembangkan jati diri yang bermakna bagi semua orang.

\section{Referensi} Jurnal Studi Amerika, vol. 5 Agustus, hal. 35-42.

Abdullah, I. (2003). Politik Bhinneka Tunggal Ika Dalam Keragaman Budaya Indonesia. Jurnal Masyarakat dan Budaya, Volume IV No. 4 Tahun 2003. 
Ahmad, Maskur. 2003. Pendidikan Kewaganegaraan Dalam Metode Praktis. Palembang.

Alfian M., M. Alfian. 2002, "Akbar Tanjung dan Etika Politik". Harian Media Indonesia, 19 Maret 2002.

Syarif Ibrahim. 2005. Sosialisasi Pluralisme dan Multikulturalisme Melalui Pendidikan. http://www.damandiri.or.id/file/ernibab2.pdf. Diakses tanggal 24 September 2006

Geger. Mengkomposisikan Integrasi sebagai Fondasi Multikulturalisme.

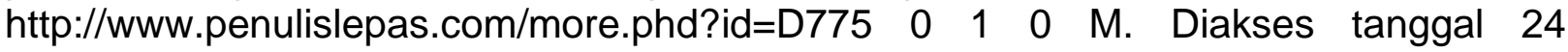
September 2006.

Huntington, Damuel. P. 2000. Benturan Antar Peradaban Dan Masa Depan Politik Dunia. Yogyakarta: Qalam.

Ibrahim, R. (2013). PENDIDIKAN MULTIKULTURAL: Pengertian, Prinsip, dan Relevansinya dengan Tujuan Pendidikan Islam. In ADDIN (Vol. 7, Issue 1). https://doi.org/10.21043/addin.v7i1.573

Khairah. (2020). Multikultural dalam Pendidikan Islam. Bengkulu: IAIN Bengkulu.

Lemabaga Ketahanan Nasional. 1998. Kewiraan Untuk Mahasiswa, Jakarta : PT Gramedia Pustaka Utama Jakarta.

Mun'im A. Sirry, Multikulturalisme dan Ambiguitas Agama, www.korantempo.com/news/2002/2/1/Opini/97.html. diakses pada 11 April 2010.

Muslimin. 2012. Pendidikan-Multikultural-Sebagai-Perekat-Budaya-Nusantara-MenujuIndonesia-Yang-Lebih-Baik. Prodising Seminar Internasional Multikurluralisme dan Globalisasi.

Puji dan Yeny, 2008. Kepemimpinan pendidikan multikultural: Tantangan dan solusinya. http://www.himpunan-Guru-Agama-Nusantara's.Blog.htm. Diakses pada 11 April 2010.

Rahman. 2005. Pentingnya Pendidikan Multikultur Atasi Konflik Etnis. http://www.gantoonline.com/index.php?option=com content\&tast=view\&id=55\&ltemid=73. Diakses tanggal 11 April 2010.

Rahmawati, W. W. D. (2014). Pendidikan Multikultural (Studi Kasus di Sekolah Lanjutan Tingkat Pertama (SLTP) di Tulungagung). In Jurnal Universitas Tulungagung BONOROWO (Vol. 2, Issue 1). https://doi.org/10.36563/BONOROWO.V2I1.32.

Solikatun, S., Masruroh, Y., \& Zuber, A. (2018). KEMISKINAN DALAM PEMBANGUNAN. Jurnal Analisa Sosiologi, 3(1), 70-90. https://doi.org/10.20961/jas.v3i1.17450.

Sumarsono S.dkk. 2002. Pendidikan kewarganegaraan, Jakarta : PT. Gramedia Pustaka Utama.

Sunarso, dkk, 2006. Pendidikan Kewarganegaraan, Yogyakarta: UNY Press.

Suparlan, Parsudi. 2002. Menuju Masyarakat Indonesia yang Multikultural. http://www.scripp.ohiou.edu/news/cmdd/artikel-ps.htm. Diakses tanggal 24 September 2006.

Tibi, Bassman. 1996. "Moralitas Internasional Sebagai suatu Landasan Lintas Budaya". Dalam Agama dan Dialog Antar Peradaban. Jakarta: Paramadina.

Tilaar, H.A.R. 2004. Multikulturalisme: Tantangan-tantangan Global Masa Depan dan Transformasi Pendidikan Nasional. Jakarta: Grassindo,

Undang-Undang Republik Indonesia No. 20 Tahun 2003 Tentang Sistem Pendidikan Nasional. 